\title{
Virtual reality as a tech tool for students studying Russian in China
}

\author{
Qiu Xin \\ Sichuan University \\ 29 Wangjianglust St, Chengdu, 610000, The People's Republic of China
}

\begin{abstract}
The article analyses the experience of implementing virtual reality (VR) in foreign language teaching, particularly teaching the Russian language in Chinese universities. Basing on different approaches and the results of applying VR in practical classes at the Russian Language Faculty of Sichuan University, the research on the effectiveness of VR technologies has been done in terms of stimulating Russian language learners' motivation, enhancing their knowledge, strengthening their language capability, developing basic oral Russian, as well as improving the quality of teaching Russian in a non-native environment. The research subject is determined by the transformation of the educational process among students with a relatively good language capability. The novelty and actuality of the topic are due to the following factors. Firstly, it is modelling situations with real-world samples when the organizer of educational process makes it immersive by using computer and recordings. Secondly, auto-reading module can be used. Thirdly, the system can check the consistency between the original text and the one recognized by voice recognition module. The author reviews indicators of the experiment, aimed at assessing teaching results and summarizing the changes in knowledge acquiring with using VR technologies at the Russian Language Faculty of Sichuan University. According to the results of the survey, the author studies the pros and cons of the changes brought by VR and concludes the opinions of the tested students and teachers participating in the experiment. The results of the experiment illustrate changing roles of teachers and students. To be specific, the teacher is no longer a simple organizer, but a supervisor, assistant and consultant, playing a supporting role. Students gradually master the functions of training systems. It stimulates them to work independently under VR. This has been proved by the students' results in the semester exam and the state accreditation test of translators. Besides, the statistical data are presented on the differences between the traditional model of language teaching and the one under VR.
\end{abstract}

Keywords: virtual reality, Russian language, Russian Language Faculty, Russian language students, Sichuan University

Article history: received: 22.01.2020; accepted: 25.03.2020.

For citation: Qiu, Xin. (2020). Virtual reality as a tech tool for students studying Russian in China. Russian Language Studies, 18(3), 328-341. http://dx.doi.org/10.22363/26188163-2020-18-3-328-341

\section{Introduction}

Mankind has entered the information age, which has caused and is causing countless changes in the world, including educational sphere. One of the specific 'labels' of modernization of contemporary education is its IT technologies. Crea-

(C) Qiu Xin, 2020

(c) () This work is licensed under a Creative Commons Attribution 4.0 International License https://creativecommons.org/licenses/by/4.0/ 
tion of Internet portals such as Second Life (USA), VILL@GE (EU), World Vision (RF), is the most important means of introducing new educational technologies for implementing the modern educational paradigm.

In China, within the framework of the 'Ten-Year Development Plan on ICT in Education (2011-2020)', a project for establishing a number of educational laboratory-type centers with the use of virtual reality technologies (hereinafter referred to as VR) was launched. Initially, the laboratories serving mainly the natural sciences were established. According to the Ministry of Education of China, only $1.7 \%$ of the total number of such laboratories occur at faculties of foreign languages including the faculty of the Russian language.

It should be noted that earlier the majority of the faculties of foreign languages already had their prototypes such as language training centers with the use of various modern audio and video equipment. Such conditions have met the 'needs' of practical training for a relatively long period of time, despite multiple disadvantages. For example, the center of simultaneous interpretation is often criticized for the monotony of the educational process. Therefore, with the introduction of VR technologies, such centers will undergo significant transformations.

Virtual reality is understood as 'a medium composed of interactive computer simulations that sense the participant's position and actions providing synthetic feedback to one or more senses, and giving the feeling of being immersed or being present in the simulation' (Sherman, Craig, 2018: 18).

By means of input/output devices bidirectional informational communication between the user and VR is carried out. Immersion, interaction and imagination are the three most distinctive features of VR (Burdea, Coiffet, 2003: 663-664).

VR simulates a 'live situation' which is lacking particularly in Russian as a foreign language classes. Visualization tools by means of VR technologies are developed to provide attractive and intuitive environments for studying visual-spatial complex topics (Hoffman, 1997: 1076-1081).

For the Russian language teaching, VR technologies, being an innovative product of informatization, have distinct advantages:

1) VR technologies remove spatio-temporal limits for traditional methods of the Russian language teaching. On the one hand, the real audience is replaced by a virtual situation, which significantly increases students' interest to the course content; on the other hand, being participants of the simulated situation allows students to connect at any time and any place, which significantly increases the level of individualized learning;

2) the stages of a class can be repeated multiple times, hence the organizers of the educational process are both teachers and students. After the necessary preparations, students can carry out different speech training independently, which makes the speech practice more flexible;

3) VR technologies give students the chance to be in situations where ordinary people find it difficult or sometimes even impossible to get into. For example, few people can participate in the UN General Assembly, but any student can become a participant and not just an outside observer in VR training sessions. 


\section{Objective}

This article is aimed to represent the system of the organization of the foreign language educational process with the use of VR technologies to intensify Chinese Russian learners' motivation for self-studying in the conditions of the extra-linguistic environment. The purpose of the article is defined by revealing all advantages and disadvantages, when using VR technologies during the Russian language classes at the Russian Language Faculty of the Institute of Foreign Languages of Sichuan University.

\section{Materials and methods}

This article is based on the results of application of VR technologies within the framework of the Russian language seminars at the Russian Language Faculty of Sichuan University. To study the effectiveness of the developed training system with the introduction of VR technologies on the basis of the Russian language subjects, a number of quasi-experimental studies to assess the results of the training and taking into account the changes in the quality of knowledge have also been carried out.

To ensure the objectivity of research indicators, the following methods are applied in this article:

- the questionnaire survey of students and teachers participated in the experiment is aimed at revealing all advantages and disadvantages of VR technologies;

- the conclusions of qualitative and quantitative analysis of the questionnaire survey and statistics on traditional and virtual classroom attendance;

- the interview with the participants of the experiment using a detailed list of questions in order to identify the real attitude of the participants to VR technologies;

- a comparative method of senior students' results of different years to determine the degree of VR technologies efficiency in the Russian language teaching.

\section{Results}

VR technologies allow students to activate independent activity in the Russian language classes. The combination of speech recognition units, automatic text voicing, and pre-graduation mechanisms play an important role in our system. On the one hand, it saves time within lesson limits, and on the other hand, it overcomes the difficulty of self-preparation. Using modern information technologies, a teacher easily adapts to the new model and turns from an organizer of the educational process when he is listening to the students' statements one by one, to a guide supervisor and a timely consultant. Based on preliminary assessments determined by a pre-arranged program the teacher can quickly learn about students' problems and provide timely individual assistance. All modeled situations can be frames used for a relatively long period of time. In addition, a set of parameters can be specifically set up for each category of students, and even for each student by which relevant situations are simulated, thus strengthening the individuality of the educational process.

The problem is that creating such laboratories and complete programs requires a huge investment. Types of simulated situations are still limited to some closed 
space such as meetings, conferences, seminars, lectures, room talks, etc. Also, a VR helmet sometimes makes students feel dizzy. Despite all the disadvantages, it is safe to assume that VR technologies models will be widely used.

\section{Discussion}

According to the data, VR technologies have hardly been practiced among Russian learners in Chinese universities before. The use of VR technologies is based on different methodological theories. According to E. Mazur, the stage of knowledge interiorization deserves attention (Mazur, 1997: 13-16), i.e. the educational process should be organized so that student could absorb the knowledge independently and to the maximum.

Situation is treated as an important factor and part of studying. Theorists have long been discussing the importance of situation in foreign languages teaching: 'Foreign languages cannot be learned by means of logical reasoning... Suggestions made by grammatical rules are used only after the context has been resolved' (Wang, 2006: 81). One cannot talk about situation without referring to B. Malinowsky concept, who regards the context of situation as the 'core' of his theory. According to B. Malinowsky the context takes into account 'linguistic and extralinguistic factors in the living speech and speech behavior realization' (Zarayskii, 1998: 97). Speech is closely related to the context of situation, which is essential for language understanding. It is not enough to rely only on intra-linguistic components for describing and analyzing speech meanings. Adequate speech understanding is possible in the context of real situation. The meaning of speech is always determined by the context of situation (Hu, 1994: 184).

The founder of the 'London School', John Rupert Firth developed the idea of B. Malinowsky and put forward the theory of context of situation. He expanded the definition of the context of situation to include the cultural background of speech and personal history of the speech act participants (Gavrilov, 2009: 26-28). M. Halliday, a J.R. Firth's student, following his teacher, justified that in reality the context always precedes the text because situation is always primary in relation to the discourse (Halliday, 1989). At the same time, Halliday showed how to combine all of the participants' speech acts with the corresponding elements to create real context of situation (Halliday, 1964). P. Davis and E. Pearse also noted that situation must be real because only in real situation a person can understand the language correctly (Davies, Pearse, 2000).

Traditional methods of the Russian language teaching are limited to speech training on different speech patterns such as speech models. In such classes different situations are recreated due to the ability of teacher-student interaction and their 'drama skills'. However, nowadays VR technologies have significantly changed the existing picture. Using VR technologies in classes spatial restrictions are removed, and the situation unfolding in front of students is a simulated 'live' situation where all necessary cultural and situational elements are shown or hidden, as in reality. As a result, speech materials and communication participants, i.e. students, are brought as close as possible.

VR technologies also meet the requirements of constructivists. 'In constructivism, cognition is not knowledge translation from objective reality into the cog- 
nizant consciousness, but the structuring of experience within the framework of the constructing function of the subject. Knowledge is a hypothetical construction that is created by an observer, not an independent existing integrity' (Sergeev, 2008: 290). With the help of VR technologies, different communication situations are created in virtual classrooms, and repeated at students' request. According to E. Mazur students, in a role of observers and participants, structure knowledge and promote the process of its interiorization themselves through repeated training.

The triad model of A. Bandura's reciprocal determinism also serves as a support for the introduction of VR technologies in the Russian language classes. According to A. Bandura, human functioning is seen as a product of interaction between behavior, personal factors, and environmental influences (Bao, 2006: 78). In the information age students have numerous channels for receiving information. The range of interest has expanded, and there is more freedom in choosing educational materials which does not always have a positive impact on students' desire to learn the language. VR technologies are changing the system and organization of traditional classes through their latest technical capabilities, hence self-efficacy is also improved to provide people with new opportunities for testing and proving their abilities.

The embodied cognition theory, representing a paradigm shift in cognitive theory in the context of continuous integration of technologies with life and high interaction between life and a learning environment, necessitates the use of VR technologies. Embodied cognition emphasizes the role of body and the impact of its interaction with the environment on cognition, which gives a person an opportunity to realize once again and determine cognitive performance. The use of the embodied cognition theory in a learning process is both embodied and situational. Included experience requires technical support for the learning environment to provide the keys to generalization and memorization. It is also reinforced and consolidated through the development learning activities (Wang, 2018: 21).

The following conditions are necessary for VR technologies to be truly operational:

1. Availability of adequate technical tools. Technical tools include VIVE WAVE, Daydream, Unity3d, Virtools, Cult3D, Visual Studio, etc., database (HBASE, Mysql, SQL Server, Oracle, etc.), and input/output devices. Obviously, we need huge upfront investments. The golden mean between capital investment and product efficiency is seen as starting point of the process.

2. Availability of carefully designed training materials. In contrast to traditional methods when using VR technologies training materials will undergo a rather strong modification. From texts, tables, pictures and schemes in training manuals they are transformed into different ready-made information blocks in the virtual world in the form of characters, and etc., with which participants should learn to establish interactive communication themselves. In most cases, teachers are not able to cope with these tasks. In our practice, we have engaged digital company experts which are co-funded by Sichuan Department of Education and Sichuan University.

3. Availability of a targeted training plan. Learning using VR technologies takes place not only in a virtual world, but also in reality. Depending on the types of classes, the level of the Russian language among students, the time allocated for 
classes with the use of VR technologies varies in the range of 10-60\%. The training plan should clearly indicate the distribution of class hours and certain methods by which the skills of students are tested.

4. Teachers' ability to manage all available resources. Technical staff is mainly involved in the preparatory phase. Teachers are responsible for the operation of the developed system and must be trained to provide smooth learning process.

5. Students' high motivation to study. Students should master modern information technology tools and learn to use devices, smartphone applications and computer programs offered to overcome all technical barriers.

Quasi-experimental research was conducted at Sichuan University at the Russian Language Faculty during 2017-2019 on the basis of the 'Oral Communication' course. The choice is based on the fact that this subject is an essential link in the Russian language module. VR technologies have a significant audiovisual character, so they 'allow to quickly transfer and assimilate new knowledge at the media level, to participate in group lecture creating in real time' (Tugova, 2019: 565). Moreover, the Russian language classes need frames-situations without time and space limits, which is the advantage of VR technologies.

According to the curriculum of Sichuan University the 'Speech Practice' discipline studied in the $4^{\text {th }}$ year is 64 hours each semester. A virtual portal of interactive type has been created on the basis of a speech training laboratory of the Institute of Foreign Languages. Twenty students can simultaneously connect to the virtual world according to the curriculum. Each participant is provided with a set of devices, including a VR helmet with soundproofed headphones, a somatosensory remote controller, and a separate workplace. The laboratory is open every working day from 9 a.m. to 5 p.m. All students have free access to all new facilities in the lab when classes are not held here.

Respondents of the research were a fourth year students. In 2017, VR technologies were not used in the learning process. They were implemented in the next two years. All the students participating in the experiment took a preliminary test, where they were asked to translate three audio recordings (each recording lasted one minute) after a single listening session.

According to the test results, the participants were divided into three A, B, C categories. Category A included students who correctly translated more than $90 \%$ of information, category B included students showed the results from 75 to $90 \%$, and category $\mathrm{C}$ included students with the results from 60 to $75 \%$. The participants' quantitative categorization is presented in Table 1.

Table 1

The amount of tested people (total \& yearly)

\begin{tabular}{ccccc}
\hline Category & Total amount & $\mathbf{2 0 1 7}$ & $\mathbf{2 0 1 8}$ & $\mathbf{2 0 1 9}$ \\
\hline A & 11 & 3 & 4 & 4 \\
\hline B & 21 & 8 & 7 & 6 \\
\hline C & 20 & 6 & 7 & 7 \\
\hline Total & & 52 & & \\
\hline
\end{tabular}


The table shows that the quantitative categorization is relatively stable. It should also be noted that in three years the teaching staff and the curriculum have remained the same, and this factor hasn't caused any significant obstacles.

The methodology using VR technologies is focused on providing the educational process with blocks of computer programs and implies division of the educational process into 5 stages:

1. The information base formation for Russian learners. It should be noted that VR technologies do not occupy the whole educational process for 'Oral Communication' course where different methods including 'flipped class' are used. Students are given various paper materials and video courses before classes for studying new words, constructions and background knowledge in advance. The first 5 minutes of each class are usually dedicated to micro tests. In other words, the teacher should determine in a short time whether the students have good information base or not. If the result is positive, it is possible to move on to the next stage; otherwise the main information should be explained.

2. Practice: practical exercise in the learning virtual world. The teacher must ensure that students' attentiveness is maintained so that they have a full immersion at this stage.

3. Control: the program quickly displays students' results and assessments of various exercises they perform after which 'practice - control' cycles are formed. The teacher interferes when a student is making the same mistake.

4. Correction: corrections, additional consultation and the information base updating. After all 'practice - control' cycles are covered, the teacher analyzes along with students common mistakes, providing references and consultation. In our practice, the last 10 minutes are focused on students' interviewing in order to solve recent problems.

5. Archive: results accumulation and processing.

The Russian language oral communication, having a complex character, includes speaking, listening, reading, writing, and translation. Therefore, we modeled 5 blocks to introduce VR technologies. Let's have a look at the translation block. The precise oral communication class is shown in Figure.

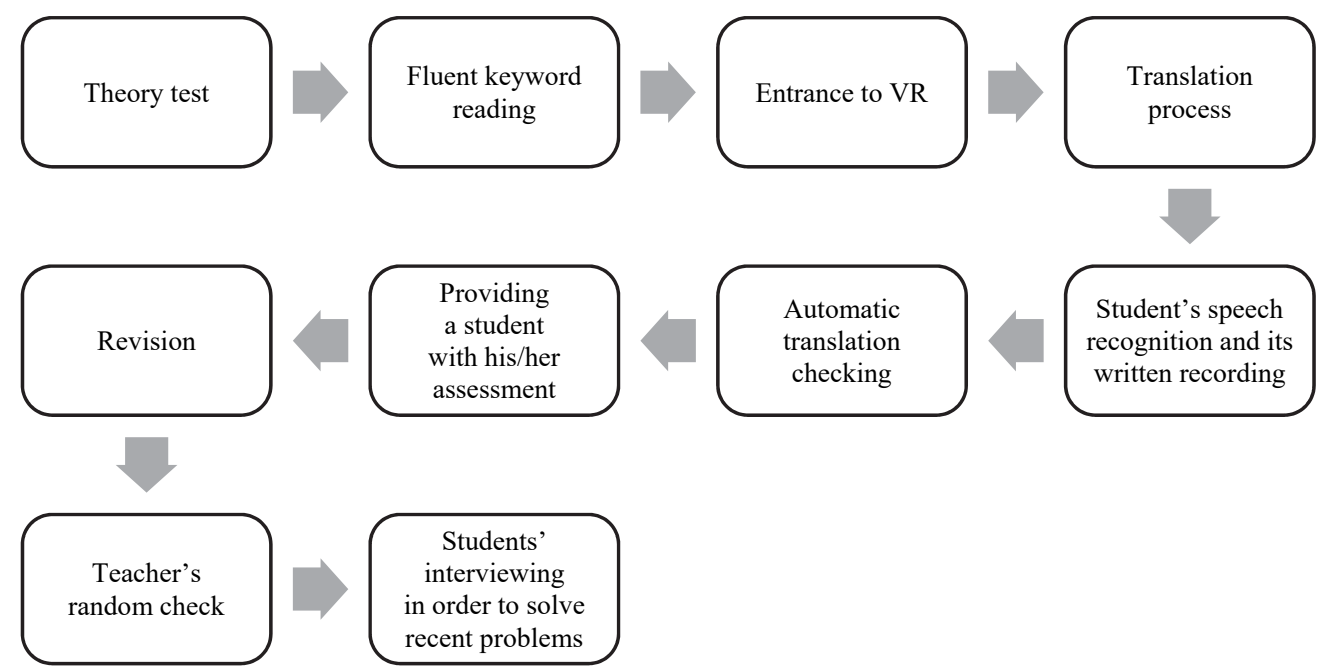

Figure. Oral communication class 
The novelty of the presented system using VR technologies is as follows:

1. Only 4 types of situations such as conference (including UN General Assembly), round table, briefing, and TED lecture based on real-world samples have been simulated. All situations are very realistic and determine 'interpreter's' location, place of objects, lighting effects, and the number of participants. When using a VR helmet a student is taking part in a simulated situation by clicking virtual buttons located on the edge of the visual field. In fact, with a VR helmet there is no need for other aids. In accordance with the process of translation in the real world all the necessary parameters are installed in advance, but students can adjust the format of the virtual situation (i.e., the parameters such as the pace of speech, male or female voice, playback time, etc.) which with the teacher's permission can be set at the entrance. This help students to get more experience of interpreting in different situations to avoid fear and stress in the future practice of the interpreter.

2. The main feature of VR is its ability to elicit a sense of 'presence' in the world created by the computer (Giuseppe, 2007: 45-56). The system we have developed allows the organizer of the learning process to enter various sound recordings depending on practical needs and to decide where to make a pause. Digital characters independently adjust their facial expressions and gestures, giving a sense of immersion. A target set of parameters can be implemented for a specific category of students or a specific student, which will be stored in a database and used in training.

3. The system has an automatic text voice acting unit. The fact is, that in practice there are often no suitable sound recordings. In this case you can simply enter written texts with pauses and enough gaps to be translated. Next, the voice is attached to the specified characters, and the training can be started.

4. With the help of the speech recognition unit the system quickly records students' interpretation in written form. Students' text is automatically compared to the text entered by the teacher before class. Preliminary assessments are made on the accuracy, fluency and completeness of the translation. If the number of mistakes or gaps exceeds the set limit, the system automatically stops the learning process and requires repeating the translation from the very beginning. Students can restart the process or apply for reading a fragment of a text recorded from the original. Based on the preliminary assessments, the teacher can selectively check the tasks and give final assessments.

The following methods were used in the quasi-experimental study:

1. Questionnaire. The questionnaire contains 30 questions on assessments of skills, knowledge, learning process, and the level of stress during classes to determine the motivation for learning. The results of the questionnaire survey made in 2018-2019 are summarized on the Likert scale. The results are presented in Table 2. Based on these results, the following conclusions can be drawn: a) VR technologies are more involved in improving skills than theoretical knowledge about Russian; b) after regular training, almost all students have become accustomed to VR technologies in the Russian language classes; c) students with a higher level of knowledge are less stressed in classes; d) students with a higher level of training are more interested in the Russian language using VR technologies. 
Questionnaire survey on VR in classes of Russian language

\begin{tabular}{lcccccc}
\hline Categories & Year & $\begin{array}{c}\text { Knowledge } \\
\text { improved }\end{array}$ & $\begin{array}{c}\text { Skills } \\
\text { improved }\end{array}$ & $\begin{array}{c}\text { Addictive } \\
\text { to VR }\end{array}$ & $\begin{array}{c}\text { Greater } \\
\text { learning } \\
\text { stress }\end{array}$ & $\begin{array}{c}\text { More interest in } \\
\text { Russian language }\end{array}$ \\
\hline \multirow{2}{*}{ Category A } & 2017 & $66,7 \%$ & $33,3 \%$ & - & $0 \%$ & $33,3 \%$ \\
& 2018 & $100 \%$ & $100 \%$ & $100 \%$ & $50 \%$ & $100 \%$ \\
\hline \multirow{2}{*}{ Category B } & 2018 & $71,4 \%$ & $71,4 \%$ & $85,7 \%$ & $42,9 \%$ & $100 \%$ \\
\hline & 2019 & $50 \%$ & $83,3 \%$ & $100 \%$ & $50 \%$ & $71,4 \%$ \\
& 2017 & $50 \%$ & $33,3 \%$ & - & $83,3 \%$ & $66,7 \%$ \\
\hline \multirow{2}{*}{ Category C } & 2018 & $57,1 \%$ & $71,4 \%$ & $100 \%$ & $85,7 \%$ & $33,3 \%$ \\
& 2019 & $42,9 \%$ & $71,4 \%$ & $85,7 \%$ & $85,7 \%$ & $42,9 \%$ \\
\hline
\end{tabular}

2. Interview. During the interview with students and teachers (4 teachers with different profile knowledge teach annually) in 2018-2019 the attention was mainly drawn to their assessments of the educational process and their proposals. All teachers consider the introduction of VR technologies to be 'effective and useful'. Three of them expressed the opinion that it is more possible to identify problem points in the knowledge system among students. Before the experiment all 4 teachers were concerned about the possibility of using the automatic text voicing unit. Three of them have changed their point of view radically, once they used it, and believe that it is an integral part of their classes. However, one of the teachers still prefers traditional methods of educating as he 'has not yet fully mastered the techniques'.

Table 3

The traditional model of teaching Russian language (model 1) and the model under VR (model 2)

\begin{tabular}{lcc}
\hline & Model $\mathbf{1}$ & Model 2 \\
\hline Educational process organizer & Teacher & Teacher and students \\
\hline Learning processor participants & Students & Teacher and students \\
\hline Types of communication in the classroom & $\begin{array}{c}\text { Teacher with students, } \\
\text { students among themselves }\end{array}$ & $\begin{array}{c}\text { Students } \\
\text { with the virtual world }\end{array}$ \\
\hline Study place & Lecture hall & Laboratory \\
\hline Learning tools & $\begin{array}{c}\text { Texts, audio, } \\
\text { video, pictures }\end{array}$ & $\begin{array}{l}\text { Complex situations } \\
\text { in the virtual world }\end{array}$ \\
\hline Interactivity & High & Average \\
\hline The reproducibility of the educational process & High & Relatively low \\
\hline
\end{tabular}

Almost all the students approved VR technologies and pointed out that thanks to VR technologies more interest in learning Russian occurred. But some students, especially those in Category $\mathrm{C}$, pointed out that sometimes the translation process 
stoped automatically due to slips of the tongue, loss of information and long reflection. This caused them anxiety and tension. Half of the students also expressed the hope that in the future they would be able to participate in essential training on their own at home, although the real conditions do not allow them to realize this intention at the moment.

Another important fact is that in 2018-2019 each test subject studied Russian for 3 hours and 12 minutes a week in the laboratory. In 2017, almost no one studied Russian out of classes. Some students complained that a VR helmet caused them dizziness and increased intraocular pressure. Three students noticed that the automatic voicing was monotonous, the features of a real person speaking were not fully simulated.

Analysis of the interview results allowed making a supposed comparison of models with/without using VR technologies (Table 3).

3. Test. Written exam at the end of each semester and CATTI (China Accreditation Test for Translators and Interpreters) has become our tool to evaluate the effectiveness of new changes in the learning process. The exam consists of four tasks: oral essay based on a microtext listening, a dialogue with 5 keywords, briefing translation from Russian into Chinese, and an international conference speech translation from Chinese into Russian. Each task was rated on a scale of 1 to 25 . The average student scores in 2018-2019 have increased by 6.3 points in comparison with ones in 2017. There is a tendency: the better students' knowledge base, the faster the situation with speaking and translation improves. For example, 6 A-category students scored over 90 points in 2018-2019. In 2017 only 1 person in the same category received 90 points. In 2018-2019 C-category students' scores increased by 3.43 points in comparison with ones in 2017 .

The use of VR technologies encourages students to participate in CATTI. Thus, there were two students in 2017, 6 students in 2018, and 7 students in 2019, who took part in CATTI. In 2018-2019 six students passed the third level test and 1 student passed the second level test, which is much complicated than the third one, in comparison with 2017 when only 1 student passed the third level test. Test results show that VR technologies have a beneficial impact on improving students' ability to speak Russian.

\section{Conclusion}

The use of VR technologies in Russian teaching in China has not yet a fullscale spread. Most of the attempts are still under discussion and point operation stage. After studying the possibilities of VR technologies in Russian oral comprehension and oral communication classes, Shao Nanxi noticed that VR is more suitable for oral comprehension classes (Shao, 2016: 85-89). Our experiment confirms her opinion. Indeed, the model using VR technology is more effective in improving communication skills. It should be emphasized that the use of MOOC (Massive Open Online Courses) and other home-made online courses oriented on theoretical knowledge explanation outside the classroom has allowed to conduct micro tests in VR simulated situation, resulting in students' much interest, patience, and motivation to prepare for the tests. Undoubtedly, students' interest towards Russian has increased thanks to VR technologies. The results of the experi- 
ment have shown that students started to attend the laboratory several times per week. The number of hours of self-training increased significantly. All these factors show a positive impact on students' success in various tests.

The automatic text voice acting, students' interpretation in written form recording, and corresponding preliminary assessments seem to form the 'axis' of the classes. Various situations make the learning process more attractive and immersive, give students real experience of using the Russian language in the practice as a real interpreter, develop their skills, and provide them with a deeper knowledge about interpreter's code and different types of interpreting. In addition, sets of parameters for a particular group of students are stored in the system and can be used over the years, which is very convenient in terms of continuity of the didactic materials accumulation for classes.

Shortcomings are definitely happening. Firstly, the main issue for teachers is to find 'cost effective modes for studying' in the digital age (Guri-Rosenblit, 2009: 114). To create an entire system, a lot of money needs to be invested. Not every institution of higher education is able and willing to spend this amount of money. Sichuan University Management has financially supported the use of VR technologies at the Russian Language Faculty. Our system is now successfully used at other faculties in the Institute of Foreign Languages, but there is clearly not enough one more laboratory to meet all needs.

Secondly, the effectiveness of VR technologies in improving skills has already been proven, but further discussion and development of methods is still required for knowledge transfer that is why theoretical explanations in 'Oral Communication' classes were provided outside classes as a part of our experiment. In other words, the classes destroy the balance between theory and practice. Thirdly, only a few types of situations were simulated in the laboratory due to technical limits. This slowed down the attempts of spreading the model using VR to other types of courses. The automatic text voice acting unit is criticized for its monotony. Fourthly, a VR helmet is expensive and heavy. In addition, long use of a VR helmet can lead to dizziness and increased intraocular pressure, which requires careful design of every detail of the learning process to protect students' health.

\section{References}

Bao, X. (2006). A review of A. Bandura's social learning theory. Cultural and educational materials, (3), 78-79. (In Chinese.)

Burdea, G., \& Coiffet, P. (2003). Virtual Reality Technology. Presence: Teleoperators and virtual environments, (6), 663-664.

Davies, P., \& Pearse, E. (2000). Success in English Teaching. London: Oxford University Press.

Gavrilova, Y. (2009). Osnovnye obshelingvisticheskiye vzglyady Dzh. R. Fersa [The main general linguistic views of J.R. Firth]. Bulletin of the Moscow State Regional University. Series: Linguistics, (2), 24-28. (In Russ.)

Giuseppe, R. (2007). Affective Interactions Using Virtual Reality: The Link between Presence and Emotions. CyberPsychology\& Behavior, (1), 45-56.

Guri-Rosenblit, S. (2009). Distance Education in the Digital Age: Common Misconceptions and Challenging Tasks. Journal of Distance Education, (2), 105-122.

Halliday, M.A.K. (1964). The Linguistic Sciences and Language Teaching. London: Longman Publ. 
Halliday, M.A.K. (1989). Language, Context and Text: Aspects of Language in a Social-Semiotic. London: Oxford University Press.

Hoffman, H. (1997). Virtual Reality: Teaching Tool of the Twenty-First Century? Academic Medicine: Journal of the Association of American Medical Colleges, (12), 1076-1081.

$\mathrm{Hu}, \mathrm{Z}$. (1994). Discourse Cohesion and Coherence. Shanghai Foreign Language Education Press. (In Chinese.)

Mazur, E. (1997). Peer Instruction: A User's Manual. Upper Saddle River, NJ: Prentice Hall Publ. Sergeev, S. (2008). Konstruktivizm: Kontsept "Znanie" [Constructivism: The concept "knowledge"]. Filosofia obrazovaniya [Philosophy of Education], (1), 286-294. (In Russ.)

Shao, N. (2016). Visual-Audio-Oral Russian Course Based on 3D Virtual Reality. Journal of Guizhou Normal University, (8), 85-89. (In Chinese.)

Sherman, W., \& Craig, A. (2018). Understanding Virtual Reality: Interface, Application, and Design. Morgan Kaufmann Publ.

Tugova, Y.A. (2019). Metodika formirovaniya lingvokul'turnoi kompetentsii inostrannykh studentov tekhnicheskogo profilya s ispol'zovaniem audiovizual'nykh tekhnologii [Methods of Formation of Linguistic-Cultural Competence of Foreign Students of a Technical Profile with the Use of Audiovisual Technologies]. International scientific and practical conference of young scientists: The study and teaching of Russian language in different linguistic and cultural environments. Moscow: RUDN University Publ. (In Russ.)

Wang, C. (2006). Foreign Language Listening, Speaking, Reading and Writing from the Perspective of the Compensation Hypothesis. Foreign Language Research, (1), 79-84. (In Chinese.)

Wang, C. (2018). Take Embodied Cognitive Theory to the Ground: Situational Interaction Supported by Technology. e-Education Research, (7), 20-26. (In Chinese).

Zarayskii, A. (1996). Problema znacheniya v zarubezhnom yazykoznanii [The problem of significance in foreign linguistics]. Saratov: Saratov University Publ. (In Russ.)

\title{
Bio note:
}

Qiu Xin, Ph.D in Philological Sciences, Dean of the Russian Language Faculty of Sichuan University. Research interests: text linguistics, teaching Russian as a foreign language, intercultural communication, general and particular problems of theory and practice of translation, cultural aspects of perception and interpretation of Chinese literature. The author of more than 20 scientific publications. E-mail: qiuxin12121@163.com

\section{Виртуальная реальность как средство обучения студентов-русистов в КНР}

\author{
Цю Синь \\ Сычуаньский университет \\ Китайская Народная Республика, 610000, Чэнду, ул. Ванизянлу, 29
}

\begin{abstract}
Аннотация. В статье представлен анализ опыта внедрения технологий виртуальной реальности (ВР) в практику обучения русскому языку в китайских вузах. На основе разных теоретических подходов и результатов применения технологий ВР в рамках практических занятий на факультете русского языка Сычуаньского университета предпринята попытка всестороннего изучения эффективности технологий ВР в плане стимуляции повышения мотивации, активизации освоения знаний, укрепления языковой
\end{abstract}


базы, выработки необходимых речевых умений и навыков у студентов-русистов, а также повышения качества преподавания русского языка в условиях внеязыковой среды. Проблема исследования определена преобразованием учебного процесса для обучающихся, имеющих относительно хорошую языковую подготовку. Обоснована новизна и актуальность представляемой системы использования технологий ВР в обучении русскому языку: моделирование ситуаций по образцам реального мира, применение организатором учебного процесса многообразных звукозаписей для достижения чувства иммерсивности посредством компьютера, использование блоков автоматической озвучки текста, распознавания речи и механизма автоматической проверки адекватности распознанного текста с оригиналом. В статье дан обзор показателей проведенного квазиэкспериментального исследования, направленного на оценку результатов обучения и учета изменений качества знаний в процессе использования технологий ВР на факультете русского языка Сычуаньского университета; по итогам анкетированного опроса рассмотрены плюсы и минусы изменений, принесенных технологиями виртуальной реальности; обобщены мнения опрошенных испытуемых студентов и преподавателей - участников эксперимента. С помощью результатов эксперимента охарактеризовано изменение ролей преподавателей и студентов. Преподаватель перестал быть простым организатором - стал контролером, помощником и консультантом, функционирующим в большей степени как поддерживающее лицо. Постепенное освоение студентами-русистами функций разных параметров в тренировочной системе стало основным фактором, стимулирующим их к самостоятельной работе в системе $\mathrm{BP}$, что доказано итоговыми результатами студентов в семестровом экзамене и государственном аккредитационном тесте переводчиков. Представлены статистические данные различия между традиционной моделью обучения русскому языку и моделью с использованием технологий виртуальной реальности.

Ключевые слова: технологии виртуальной реальности, русский язык, факультет русского языка, студенты-русисты, Сычуаньский университет

История статьи: поступила в редакцию: 22.01.2020; принята к печати: 25.03.2020.

Для цитирования: Qiu Xin. Virtual reality as a tech tool for students studying Russian in China // Русистика. 2020. T. 18. № 3. С. 328-341. http://dx.doi.org/10.22363/2618-81632020-18-3-328-341

\section{Список литературы}

Бао Сяофэн. Обзор теории социального обучения А. Бандуры // Культурно-просветительные материалы. 2006. № 3. С. 78-79.

Ван Цисяо. Реализация теории воплощенного познания: контекстное взаимодействие с техподдержкой // Изучение компьютерного обучения. 2018. № 7. С. 20-26.

Ван Чумин. Рассмотрение аудирования, говорения, чтения и письма с точки зрения компенсационной гипотезы // Изучение иностранных языков. 2006. № 1. С. 79-84.

Гаврилова Ю.В. Основные общелингвистические взгляды Дж. Р. Ферса // Вестник Московского государственного областного университета. Серия: Лингвистика. 2009. № 2. С. 24-28.

Зарайский А.А. Проблема значения в зарубежном языкознании. Саратов: Изд-во Саратовского университета, 1996. $150 \mathrm{c.}$

Сергеев С.Ф. Конструктивизм: концепт «знание» // Философия образования. 2008. № 1. C. 286-294.

Тугова Ю.А. Методика формирования лингвокультурной компетенции иностранных студентов технического профиля с использованием аудиовизуальных технологий // Изучение и преподавание русского языка в разных лингвокультурных средах: Международная научно-практическая конференция молодых ученых (Москва, РУДН, 23-24 сентября 2019 г.): труды и материалы / под общ. ред. В.М. Шаклеина. М.: РУДН, 2019. С. 561-570. 
Ху Чжсуанлинь. Когезия и когерентность дискурса. Шанхай: Шанхайское издательство «Преподавание иностранных языков», 1994. 235 с.

Шао Наньси. О визуально-аудио-устном обучении русскому языку на основе виртуальной трехмерной ситуации // Вестник Гуйчжоуского педагогического университета. 2016. № 8. С. 85-89.

Burdea G., Coiffet P. Virtual Reality Technology // Presence: teleoperators and virtual environments. 2003. No. 6. Pp. 663-664.

Davies P., Pearse E. Success in English Teaching. London: Oxford University Press, 2000. 236 p.

Giuseppe R. Affective Interactions Using Virtual Reality: The Link between Presence and Emotions // CyberPsychology \& Behavior. 2007. No. 1. Pp. 45-56.

Guri-Rosenblit S. Distance Education in the Digital Age: Common Misconceptions and Challenging Tasks // Journal of Distance Education. 2009. No. 2. Pp. 105-122.

Halliday M.A.K. Language, Context, and Text: Aspects of Language in a Social-Semiotic. London: Oxford University Press, 1989. 126 p.

Halliday M.A.K. The Linguistic Sciences and Language Teaching. London: Longman, 1964. $322 \mathrm{p}$.

Hoffman H. Virtual Reality: Teaching Tool of the Twenty-First Century? // Academic Medicine: Journal of the Association of American Medical Colleges. 1997. No. 12. Pp. 1076-1081.

Mazur E. Peer Instruction: A User's Manual. Upper Saddle River, NJ: Prentice Hall, 1997. 253 p.

Sherman $W$., Craig A. Understanding Virtual Reality: Interface, Application, and Design. Morgan Kaufmann Publishers, 2018. 938 p.

\section{Сведения об авторе:}

Цю Синь, кандидат филологических наук, декан факультета русского языка Сычуаньского университета. Сфера научных интересов: лингвистика текста, преподавание русского языка как иностранного, межкультурная коммуникация, общие и частные проблемы теории и практики перевода, культурологические аспекты восприятия и интерпретации литературы Китая. Автор более 20 научных публикаций. E-mail: qiuxin12121@163.com 